Vol. 19(2010): 233-239.

\title{
Egg performance, egg quality, and nutrient utilization in laying hens fed diets with different levels of rapeseed expeller cake
}

\author{
Sylwester Świątkiewicz*, Jerzy Koreleski and Anna Arczewska-Włosek \\ National Research Institute of Animal Production, Department of Animal Nutrition and Feed Science, \\ 32-083 Balice, Poland, *e-mail: sylwester.swiatkiewicz@izoo.krakow.pl
}

\begin{abstract}
The aim of this study was to evaluate the effect of different levels of rapeseed expeller cake (RC) in the diet of laying hens on egg performance, egg quality, retention and excretion of nitrogen, calcium and phosphorus, and metabolizability of energy. The experiment was carried out with 72 Bovans Brown hens, from 28 to 53 weeks of age. Experimental treatment consisted of four isonitrogenous and isocaloric corn-soybean diets (as calculated: $17 \%$ crude protein, $11.6 \mathrm{MJ} / \mathrm{kg}$ metabolizable energy, $0.81 \%$ lysine, $0.36 \%$ methionine, $3.60 \%$ calcium and $0.37 \%$ available phosphorus), containing $0,4,6$ or $8 \%$ RC. The RC used was produced from double zero rapeseed and contained $29.3 \%$ crude protein, $17.4 \%$ crude fat, $10.8 \%$ crude fibre, $0.63 \%$ calcium, $0.97 \%$ phosphorus, $1.91 \%$ lysine and $0.84 \%$ methionine. During the experimental period, the dietary level of RC had no significant effects on egg performance and egg quality parameters. Boiled eggs from hens fed a diet with $8 \% \mathrm{RC}$ were characterized by an inferior flavour to those from other groups. There were no treatment effects on nitrogen balance or metabolizability of energy, though the highest dietary level of RC negatively affected retention and excretion of calcium and phosphorus.
\end{abstract}

Key-words: rapeseed expeller cake, laying hens, egg performance, egg quality, nutrient retention

\section{Introduction}

Rapeseed expeller cake (RC) is a high-protein coproduct of industrial oil extraction, obtained from the mechanical pressing of seeds. In recent years in central and northern Europe, this method of oil extraction has come to be used, especially in the production of biodiesel. As biodiesel is a renewable source of energy, and burns with low carbon dioxide emissions, global production of biodiesel from vegetable oils continues to increase rapidly, and further large growth is expected in the future. 
Światkiewicz, S. et al. Rapeseed cake in layer diets

This growth will result in an enlarged quantity of RC available to feed producers. The European Union has supported biofuels production in order to diversify energy supplies, reduce greenhouse gas emission and dependency on oil and to create additional employment in rural areas (Świątkiewicz and Koreleski 2008)

Rapeseed cake contains a considerable amount of protein, rich in sulphur amino acids, and, because of its higher crude fat level and lower fibre content, RC is a richer source of metabolizable energy for monogastric animals as compared to solvent-extracted rapeseed meal. The content of anti-nutritive factors, such as glucosinolate and erucic acid, in rapeseed, has been reduced during the last 20 years by plant breeding programmes, so the risk in the use of rapeseed products as animal feed has too been reduced. The results of previous experiments have demonstrated that $\mathrm{RC}$ can be used as a feed component in the diets of broiler chickens (Suchy et al. 2002, Peter and Dänicke 2003, Smulikowska et al. 2006), pigs (Schöne et al. 1997, Schöne et al. 2002) and ruminants (Göpfert et al. 2006). The effects of untreated or extruded rapeseed and extracted rapeseed meal on performance indices and egg quality in layers have been studied (Kamińska 2003, Lichovnikova and Zeman 2004, Lichovnikova et al. 2008), but data on the use of rapeseed expeller cake as a feed component for hens are very limited.

The aim of the present study conducted on laying hens was to evaluate the effect of the dietary level of rapeseed expeller cake on egg performance, egg quality, retention and excretion of nitrogen, calcium and phosphorus, and metabolizability of energy.

\section{Material and Methods}

\section{Birds and experimental diets}

A total of seventy-two, 18-wk-old, Bovans Brown hens, obtained from a commercial source, were placed in the poultry house, in individual cages, on a wire-mesh floor, and under controlled climate conditions. The cage dimensions were $40 \mathrm{~cm} \times 40 \mathrm{~cm}$ $\times 45 \mathrm{~cm}$, equating to $1600 \mathrm{~cm}^{2}$ total floor space. During the pre-experimental period (up to $28 \mathrm{wks}$ of age), a commercial laying hen diet (17\% crude protein, $11.6 \mathrm{MJ} / \mathrm{kg}$ nitrogen-corrected apparent metabolizable energy $\left(\mathrm{AME}_{\mathrm{N}}\right), 3.70 \%$ calcium and $0.38 \%$ available phosphorus) was offered ad libitum.

At 28 wks of age, the hens were randomly assigned one of four treatments, each comprising 18 , individually caged layers. During the experiment, the hens had free access to feed and water, and were exposed to a lighting schedule of $14 \mathrm{~h}$ of light and $10 \mathrm{~h}$ of darkness, with a ligh intensity of 10 lux. The Local Krakow Ethics Committee for Experiments with Animals approved all the experimental procedures relating to the use of live animals.

The rapeseed expeller cake sample (Table 1) used in this study was obtained from a commercial biodiesel production facility (GES Inc., Bidziny, Poland). The cakes were produced from winter

Table 1. Chemical composition of rapeseed expeller cakes used in experiment ( $\mathrm{g} / \mathrm{kg}$, 'as is' basis)

\begin{tabular}{lc}
\hline Item & \\
\hline Dry matter & 913 \\
Crude protein & 293 \\
Crude fat & 174 \\
Crude fibre & 108 \\
Nitrogen free extract & 337 \\
Calcium & 6.28 \\
Phosphorus & 9.68 \\
Methionine & 8.41 \\
Lysine & 19.1 \\
Cystine & 7.25 \\
Threonine & 13.8 \\
Tryptophan & 3.44 \\
Arginine & 16.3 \\
Valine & 14.6 \\
Isoleucine & 10.1 \\
Leucine & 20.0 \\
Phenyloalanine & 11.6 \\
Tyrosine & 9.28 \\
Histidine & 7.93 \\
Aspartic acid & 22.8 \\
Serine & 13.8 \\
Proline & 18.9 \\
\hline
\end{tabular}


Vol. 19(2010): 233-239.

double zero rapeseed of unknown cultivar and contained $23.6 \mu \mathrm{mol}$ total glucosinolates per $\mathrm{kg}$ of dry matter, consisting of $(\mu \mathrm{mol} / \mathrm{kg} \mathrm{DM}) 7.5$ progoitrin, 2.8 gluconapin, 1.4 glucobrassicanapin, 0.91 gluconapoliferin, 4.8 4-hydroxyglucobrassicin, 1.0 glucobrassicin and lower amounts of further glucosinolates (as analysed in the laboratory of the National Research Institute of Animal Production in Balice, using the HPLC, according to ISO 91671, 1992). During the production process, rapeseeds were heated to $50^{\circ} \mathrm{C}$ and pressed in a screw press (Alimentarmash, Kishinev, Moldova).
Experimental isonitrogenous and isocaloric corn-soybean diets were formulated to meet or exceed nutrient recommendations (NRC 1994) and contained $0,4,6$ or $8 \%$ rapeseed expeller cake (Table 2).

\section{Chemical analysis}

The experimental diets were fed from 28 to 53 wks of age. The nutrient content of the diets was calculated according to the chemical composition

Table 2. Composition and nutrient content of experimental diets (\%)

\begin{tabular}{|c|c|c|c|c|}
\hline \multirow[t]{2}{*}{ Item } & \multirow[t]{2}{*}{ Control } & \multicolumn{3}{|c|}{ Rapeseed expeller cake (\%) } \\
\hline & & 4 & 6 & 8 \\
\hline Corn & 35.50 & 35.50 & 35.50 & 35.50 \\
\hline Wheat & 25.65 & 23.96 & 23.26 & 22.57 \\
\hline Soybean meal & 23.00 & 20.70 & 19.40 & 18.10 \\
\hline Grass meal & 2.00 & 2.00 & 2.00 & 2.00 \\
\hline Rapeseed expeller cake & - & 4.00 & 6.00 & 8.00 \\
\hline Rapeseed oil & 2.50 & 2.50 & 2.50 & 2.50 \\
\hline Limestone & 8.80 & 8.80 & 8.80 & 8.80 \\
\hline Dicalcium phosphate & 1.65 & 1.65 & 1.65 & 1.65 \\
\hline $\mathrm{NaCl}$ & 0.30 & 0.30 & 0.30 & 0.30 \\
\hline DL-Methionine (99\%) & 0.10 & 0.09 & 0.09 & 0.08 \\
\hline Vitamin-mineral premix ${ }^{1}$ & 0.50 & 0.50 & 0.50 & 0.50 \\
\hline Total & 100.00 & 100.00 & 100.00 & 100.00 \\
\hline \multicolumn{5}{|l|}{ Composition (on as-is basis) } \\
\hline \multicolumn{5}{|l|}{ Calculated values: } \\
\hline Metabolizable energy $^{2}, \mathrm{MJ} / \mathrm{kg}$ & 11.6 & 11.6 & 11.6 & 11.6 \\
\hline Crude protein & 17.0 & 17.0 & 17.0 & 17.0 \\
\hline Lys & 0.815 & 0.815 & 0.811 & 0.808 \\
\hline Met & 0.363 & 0.362 & 0.365 & 0.360 \\
\hline $\mathrm{Ca}$ & 3.66 & 3.67 & 3.70 & 3.72 \\
\hline Total P & 0.60 & 0.64 & 0.67 & 0.72 \\
\hline Available P & 0.37 & 0.37 & 0.37 & 0.37 \\
\hline \multicolumn{5}{|l|}{ Analyzed values: } \\
\hline Crude protein & 17.9 & 17.8 & 17.5 & 17.6 \\
\hline $\mathrm{Ca}$ & 3.55 & 3.55 & 3.50 & 3.46 \\
\hline Total P & 0.66 & 0.69 & 0.71 & 0.72 \\
\hline
\end{tabular}

${ }^{1}$ The premix provided, per $1 \mathrm{~kg}$ of diet: vitamin A, 10,000 IU; vitamin D3, 3,000 IU; vitamin E, $50 \mathrm{IU}$; vitamin K3, $2 \mathrm{mg}$; vitamin B1, $1 \mathrm{mg}$; vitamin B2, $4 \mathrm{mg}$; vitamin B6, $1.5 \mathrm{mg}$; vitamin B12, $0.01 \mathrm{mg}$; Ca-pantotenate, $8 \mathrm{mg}$; niacin, $25 \mathrm{mg}$; folic acid, $0.5 \mathrm{mg}$; choline chloride, 250 mg; manganese, $100 \mathrm{mg}$; zinc, $50 \mathrm{mg}$; iron, $50 \mathrm{mg}$; copper, $8 \mathrm{mg}$; iodine, $0.8 \mathrm{mg}$; selenium, $0.2 \mathrm{mg}$, cobalt, $0.2 \mathrm{mg}$.

${ }^{2}$ Calculated according to European Table (Janssen, 1989) as a sum of the ME content of components. 
Światkiewicz, S. et al. Rapeseed cake in layer diets

of raw feedstuffs, and metabolizable energy value, with the accordance the equations from the European Tables (Janssen 1989). The ingredients were analyzed, using standard methods (AOAC 1990), for moisture (method 930.15), crude protein (984.13), crude fat (920.39) and ash (942.05). Amino acids were analyzed in acid hydrolysates, after initial performic acid oxidation of sulfur amino acids and after alkaline hydrolysis of tryptophan (AOAC 1990; method 982.30). Calcium content was analyzed by flame atomic absorption spectrophotometry (AOAC 1990; method 968.08) and total phosphorus content colorimetrically, by the molybdo-vanadate method (AOAC 1990; method 965.17). For the balance study, nitrogen content in the diets and excreta was analyzed using the Kjeldahl procedure (AOAC 1990; method 984.13), gross energy, using an adiabatic bomb calorimeter, total phosphorus content colorimetrically, by the molybdo-vanadate method (AOAC 1990; method 965.17) and calcium content by flame atomic absorption spectrophotometry (AOAC 1990; method 968.08).

\section{Measurements}

During the experiment, the number and weight of eggs were registered daily, feed consumption was recorded monthly, and laying rate, daily egg production, daily feed intake and feed conversion ( $\mathrm{g}$ of feed consumed per $1 \mathrm{~g}$ of produced eggs) were calculated.

At 48 wks of age, one egg was collected from each hen (18 eggs from each treatment) in order to determine egg quality indices, i.e. albumen height, Haugh Units, yolk color, eggshell thickness and eggshell density. The eggs were analyzed using semi-automated egg quality equipment (QCM+, Technical Services and Supplies (TSS), York, UK). The eggs were weighed, cracked, and the albumen height was measured with an electronic gauge (QCH device, TSS, York, UK). The albumen height was converted to Haugh units using the HU formula (Eisen et al. 1962) by Eggware software (TSS, York, UK). Yolk color was measured using an electronic colorimeter (QCC device, TSS, York, UK) and expressed in Roche scale points. Shell thickness was measured near the equator of the egg using an electronic micrometer (QCT device, TSS, York, UK). Eggshell density (the dried shell weight per unit of shell area, $\mathrm{mg} / \mathrm{cm}^{2}$ ) was calculated by Eggware software (TSS, York, UK).

An additional 18 eggs from each treatment were collected for measurements of eggshell breaking strength, using an Instron Testing Machine, Model 5542 (Instron Ltd., High Wycombe, England), equipped with a 500 Newton load cell. The eggs were compressed at a constant crosshead speed of $10 \mathrm{~mm} / \mathrm{min}$ and the breaking strength was determined at the moment of eggshell fracture. At the end of the experiment (53 weeks of age), one egg from each layer was collected for determination of sensory parameters. After boiling for $10 \mathrm{~min}$, the eggs were evaluated by a 6-person panel. The panelists ranked the flavour and taste of the eggs on a 4-point scale (from 2 to 5) for the degree of liking (2 - flavour and taste unacceptable, 3 - acceptable, 4 - good, 5 - very good).

At 38 wks of age, five hens from each treatment were placed into individual balance cages (the cage dimensions were $35 \mathrm{~cm} \times 42 \mathrm{~cm} \times 45 \mathrm{~cm}$, equating to $1470 \mathrm{~cm}^{2}$ total floor space). After a one-week adaptation period, a total collection of excreta was carried out over 5 days, and feed consumption for each hen was recorded. The excreta were stored in plastic bags at $-20^{\circ} \mathrm{C}$ for two weeks and, after thawing, were dried in an oven at $50{ }^{\circ} \mathrm{C}$ to a constant weight, then weighed and finely ground. Nitrogen (calcium, phosphorus) retention (mg) was calculated as: nitrogen intake - nitrogen excretion. Nitrogen (calcium, phosphorus) retention as \% of nitrogen (calcium, phosphorus) intake was calculated as: nitrogen intake - (nitrogen intake - nitrogen excretion) $/$ nitrogen intake $\times 100$. Dietary apparent $\mathrm{AME}_{\mathrm{N}}$, was calculated by the following formula: $\mathrm{AME}_{\mathrm{N}}=$ [gross energy intake - gross energy excretion $]-[$ (nitrogen intake - nitrogen excretion $) \times$ 8.73 ] / feed intake, where 8.73 is the nitrogen correction factor (Titus et al. 1959). Energy utilization in the diets with different levels of RC was calculated as $\%$ of $\mathrm{AME}_{\mathrm{N}}$ in the gross energy of the diets. 
Vol. 19(2010): 233-239.

\section{Statistical Analysis}

All data were subjected to statistical analysis using one-way ANOVA. When significant differences in treatment means were detected by ANOVA (F-test), Duncan's multiple range test was applied to separate means. Differences were considered significant at $p$ $<0.05$. All statistical analyses were performed with Statistica 5.0 PL software (Statsoft, Inc.).

\section{Results and Discussion}

The chemical composition of the rapeseed expeller cake being studied (Table 1) was similar to the composition of other RCs obtained using the same technique and previously reported by Schöne et al. (1997, 2002) and Smulikowska et al. (2006). The mean laying rate, across all dietary treatments, and the entire experimental period (between 28-53 wks of hen age) was $94.6 \%$; egg weight, $59.6 \mathrm{~g}$; daily egg production, $56.4 \mathrm{~g} / \mathrm{hen}$; daily feed consumption, $116 \mathrm{~g} /$ hen and feed conversion per $1 \mathrm{~g}$ of eggs, 2.06 $\mathrm{g}$ (Table 3). The inclusion of 4,6 or $8 \% \mathrm{RC}$ had no significant effect on egg performance parameters in comparison with the hens fed the control diet $(p>$ 0.05 ). The results of the present study were similar to those reported by Obadalek et al. (1997), who found, in an experiment with Hisex Brown hens, that egg production and egg weight were not affected when 3,6 or $9 \% \mathrm{RC}$ was incorporated into the diet. Horniakova and Sojkova (1996) reported that the replacement of soybean meal in the diets of layers with RC at up to $18.5 \%$ had no negative effect on laying performance, but when RC was substituted for soybean meal at 55 or $100 \%$, a reduction in performance was observed. In fattened pigs, 7.5\% $\mathrm{RC}$ had no effect on performance, but a higher dietary level of RC (15\%) negatively affected feed intake and body weight gain (Schöne et al. 1997, Schöne et al. 2002).

The inclusion level of RC had no effect on egg quality parameters. i. e. albumen height, Haugh units, yolk color and egg shell thickness, density and breaking strength (Table 3). Similarly, Obadalek et al. (1997) found no effect of the dietary level of RC $(3,6$ or $9 \%)$, except for moderate yolk depigmentation at the highest level of RC.

Table 3. Effect of dietary level of rapeseed expeller cake on egg performance and egg quality

\begin{tabular}{lccccc}
\hline Item & \multicolumn{3}{c}{ Dietary rapeseed expeller cake (\%) } & \multirow{2}{*}{ SEM } \\
\cline { 2 - 4 } & 0 & 4 & 6 & 8 & \\
\hline Laying rate, \% & 94.5 & 94.2 & 94.9 & 94.8 & 0.45 \\
Egg weight, g & 59.3 & 59.0 & 60.3 & 59.8 & 0.30 \\
Daily egg production, g per hen & 56.0 & 55.6 & 57.2 & 56.7 & 0.51 \\
Daily feed consumption, g per hen & 115 & 116 & 117 & 115 & 0.54 \\
Feed conversion, g of feed per 1g of eggs & 2.06 & 2.09 & 2.05 & 2.03 & 0.02 \\
Albumen height, mm & 6.31 & 6.57 & 6.02 & 6.44 & 0.12 \\
Haugh units & 78.3 & 80.9 & 76.9 & 77.4 & 0.97 \\
Yolk color, Roche scale points & 3.67 & 3.67 & 3.67 & 3.58 & 0.76 \\
Eggshell thickness, $\mu \mathrm{m}$ & 382 & 395 & 406 & 400 & 4.42 \\
Eggshell density, mg/cm ${ }^{2}$ & 92.7 & 92.6 & 93.4 & 98.4 & 1.23 \\
Eggshell breaking strength, $\mathrm{N}$ & 33.1 & 34.3 & 33.4 & 34.8 & 1.12 \\
Flavour of boiled eggs, points & $4.10 \mathrm{a}$ & $4.06 \mathrm{a}$ & $4.07 \mathrm{a}$ & $3.67 \mathrm{~b}$ & 0.03 \\
Taste of boiled eggs, points & 4.15 & 4.10 & 4.07 & 3.96 & 0.03 \\
\hline
\end{tabular}

$\mathrm{a}, \mathrm{b}$ - means in rows with different letters differ significantly at $p \leq 0.05$ 
Światkiewicz, S. et al. Rapeseed cake in layer diets

Table 4. Effect of dietary level of rapeseed expeller cake on N, Ca and P balance and on metabolizability of dietary energy

\begin{tabular}{|c|c|c|c|c|c|}
\hline \multirow[t]{2}{*}{ Item } & \multicolumn{4}{|c|}{ Dietary rapeseed expeller cake $(\%)$} & \multirow{2}{*}{ SEM } \\
\hline & 0 & 4 & 6 & 8 & \\
\hline $\mathrm{N}$ excretion, mg/hen per day & 2007 & 2022 & 1973 & 2045 & 41.6 \\
\hline $\mathrm{N}$ retention, $\mathrm{mg} / \mathrm{hen}$ per day & 1462 & 1539 & 1332 & 1407 & 35.9 \\
\hline $\mathrm{N}$ retained, $\%$ of $\mathrm{N}$ intake & 42.1 & 43.2 & 40.2 & 40.9 & 0.73 \\
\hline $\mathrm{Ca}$ excretion, $\mathrm{mg} /$ hen per day & $1489^{a}$ & $1575^{\mathrm{a}}$ & $1685^{\mathrm{ab}}$ & $1907^{\mathrm{b}}$ & 55.7 \\
\hline $\mathrm{Ca}$ retention, $\mathrm{mg} / \mathrm{hen}$ per day & $2353^{\mathrm{a}}$ & $2396^{\mathrm{a}}$ & $2105^{\mathrm{ab}}$ & $1885^{\mathrm{b}}$ & 65.3 \\
\hline Ca retained, $\%$ of $\mathrm{Ca}$ intake & $61.2^{\mathrm{a}}$ & $60.3^{\mathrm{a}}$ & $55.5^{\mathrm{ab}}$ & $49.8^{b}$ & 1.31 \\
\hline $\mathrm{P}$ excretion, $\mathrm{mg} / \mathrm{hen}$ per day & 573 & 614 & 615 & 665 & 14.1 \\
\hline $\mathrm{P}$ retention, $\mathrm{mg} / \mathrm{hen}$ per day & $172^{\mathrm{a}}$ & $156^{\mathrm{a}}$ & $145^{\mathrm{ab}}$ & $110^{\mathrm{b}}$ & 8.24 \\
\hline $\mathrm{P}$ retained, $\%$ of $\mathrm{P}$ intake & $23.0^{\mathrm{a}}$ & $20.3^{\mathrm{ab}}$ & $19.1^{\mathrm{ab}}$ & $14.2^{\mathrm{b}}$ & 1.07 \\
\hline $\begin{array}{l}\text { Metabolizability of energy, } \% \text { of } \mathrm{AME}_{\mathrm{N}} \text { in the } \\
\text { gross energy of the diet }\end{array}$ & 68.7 & 67.0 & 66.8 & 67.5 & 0.36 \\
\hline
\end{tabular}

a, b - means in rows with different letters differ significantly at $p \leq 0.05$

In our study, a 4 or $6 \%$ inclusion level of RC had no effect on the flavour and taste of boiled eggs; however the highest dietary level of RC (8\%) negatively affected the eggs' sensory properties (Table 3). A similar effect was reported by Lichovnikova et al. (2008), who used experimental diets containing 8 or $10 \%$ untreated rapeseed. The worsening of eggs' sensoric properties can be linked to the presence of trimethylamine in the yolks when a high level of rapeseed products is used in the diet. It is well known that some brown layers may have a deficiency of oxidase trimethyloamine, an enzyme which converts trimethylamine to odourless products (Butler and Fenwick 1984). The negative effect of rapeseed cake (15\% of the diet) on the sensory characteristics of animal origin products (meat) was also observed in pigs (Schöne et al. 2002).

During the balance study, the mean laying rate, across all dietary treatments, was $91.9 \%$; egg weight, $60.1 \mathrm{~g}$; daily egg production, $54.9 \mathrm{~g} / \mathrm{hen}$; daily feed consumption, $116 \mathrm{~g} /$ hen and feed conversion per $1 \mathrm{~g}$ of eggs, $2.11 \mathrm{~g}$; these values did not vary between treatments $(p>0.05)$. The results of the balance study showed no significant effect of the RC dietary inclusion level on the retention and excretion of nitrogen or the percentage of $\mathrm{AME}_{\mathrm{N}}$ in the gross energy in the diet (Table 4). In diets with $0,4,6$ and $8 \%$ RC, $\mathrm{N}$ balances and metaboliz- ability of energy behaved similarly $(p>0.05)$. For comparison, in an experiment with broiler chickens, Smulikowska et al. (2006) found the relative $\mathrm{N}$ retention (as \% of $\mathrm{N}$ intake) to be $44.7 \%$, and content of $\mathrm{AME}_{\mathrm{N}}$ in gross energy of rapeseed cake to be $55.1 \%$ (Smulikowska et al. 2006).

The dietary treatment was found to have a significant effect on $\mathrm{Ca}$ and $\mathrm{P}$ balances (Table 4). The introduction of $8 \% \mathrm{RC}$ to the diet negatively affected the utilization of these minerals. In hens fed a diet with $8 \% \mathrm{RC}$, excretion of $\mathrm{Ca}$ and $\mathrm{P}$ was higher, and retentions were lower as compared with other experimental treatments $(p \leq 0.05)$. Based on the data in the literature, it may be stated that the main reason for the reduced availability of minerals in rapeseed is the high content of phytate in this plant (Nwokolo and Bragg 1977, Fenwick 1982, Żyła and Koreleski 1993). About two-thirds of the phosphorus in rapeseed is bound to phytate and is unavailable for poultry (Nelson 1976). Our results correspond with data from an experiment with layers, where the addition of phytase to a diet with a high level of rapeseed meal (15\%), significantly improved calcium and phosphorus availability (Sasyte et al. 2006). Similar results were obtained in a study with broilers fed a diet with $15 \%$ rapeseed meal, using mineralization of the tibia bone as an indicator of phosphorus utilization (Żyła and Koreleski 1993). As compared to 
Vol. 19(2010): 233-239.

control group, the significantly higher excretion of $\mathrm{P}$ in layers fed with $8 \%$ of rapeseed expeller cake has obvious environmental implications in relation to the pollution potential of hen's excreta. Since Um and Paik (1999) have shown that addition of phytase to a low P layer's diet containing rapeseed meal reduced $\mathrm{P}$ excretion by as much as $41 \%$, it seems that the use of this enzyme could prove to be an efficient way of improving the $\mathrm{P}$ availability in poultry diets containing rapeseed by-products. Addition of phytase, simultaneously with acid phosphatase, pectinase and citric acid, to a diet for broiler chickens, reduced the amount of $P$ excreted by $56 \%$ (Żyła et al. 2001).

In conclusion, the results of this study have demonstrated that rapeseed cake produced from double zero cultivars may be incorporated to a level of $6 \%$ in the diet of laying hens with no detrimental effect on egg performance and egg quality. Higher levels of RC (8\%) may negatively affect the utilization of calcium and phosphorus and the sensoric properties of boiled eggs.

\section{References}

AOAC 1990. Official Methods of Analysis. $15^{\text {th }}$ ed. Association of Official Analytical Chemists. Arlington, VA, USA

Butler, E.J. \& Fenwick, G.R. 1984. Trimethyloamine and fishy taint in eggs. World's Poultry Science Journal 40: 38-51.

Eisen, E.J., Bohren, B.B. \& McKean, K.E. 1962. The Haugh unit as a measure of egg albumen quality. Poultry Science 41: 1461-1468.

Fenwick, G. R. 1982. The assessment of a new protein source - rapeseed. Proceedings of Nutrition Society 41: 277-282.

Göpfert, E., Trckova, M. \& Dvorak., M. 2006. The use of treated rape cake in a calf starter diet. Czech Journal of Animal Science 51: 491-501.

Horniakova, E. \& Sojkova, Z. 1996. Using the rape cake in the feeding of laying hens. Acta Zootechnica 51: 83-87.

ISO 9167-1, 1992. Rapeseed - Determination of glucosinolate content. Part 1. Method using high-performance liquid chromatography. International Organization for Standardization (ISO), Geneva, p. 8.

Janssen, W.M.M.A. 1989. European Table of Energy Values for Poultry Feedstuffs. 3rd ed. Working Group No. 2 of the European Branch, World's Poult. Sci. Assoc., Beekbergen, The Netherlands.

Kamińska, B.Z. 2003. Substitution of soyabean meal with
"00" rapeseed meal or its high protein fraction in the nutrition of hens laying brown-shelled eggs. Journal of Animal Feed Sciences 12: 111-119.

Lichovnikova, M. \& Zeman, L. 2004. The effects of a higher iodine supplement on the efficiency of laying hens fed extruded rapeseed and on eggshell quality. Czech Journal of Animal Science 49: 199-203.

Lichovnikova, M., Zeman, L. \& Jandasek, J. 2008. The effect of feeding untreated rapeseed and iodine supplement on egg quality. Czech Journal of Animal Science 53: 77-82.

Nelson, TS. 1976. The hydrolysis of phytate phosphorus by chicks and laying hens. Poultry Science 55: 2262-2264.

NRC. 1994. Nutrient requirements of poultry. 9th ed. Natl. Acad. Press, Washington, DC.

Nwokolo, E.N. \& Bragg, D.B. 1977. Influence of phytic acid and crude fiber on the availability of minerals from four protein supplements in growing chicks. Canadian Journal of Animal Science 57: 475-477.

Obadalek, J., Vymola, J. \& Kosar, K. 1997. Rapeseed cake in laying hen diets. Zivocisna Vyroba 42: 23-26.

Peter, W. \& Dänicke, S. 2003. Investigations on the use of rape cake meal in the feeding of slow growing Label broilers. Archive für Geflügelkunde 67: 253-260.

Sasyte, V., Raceviciute-Stupeliene, A., Gruzauskas, R. \& Mosenthin, R. 2006. Effect of phytase on P and Ca utilization at different age periods of laying hens fed higher amount of rapeseed meal. Biologija 1: 69-72.

Schöne, F., Rudolph, B., Kirchheim, U. \& Knapp, G. 1997. Counteracting the negative effects of rapeseed and rapeseed press cake in pig diets. British Journal of $\mathrm{Nu}$ trition 78: 947-962.

Schöne, F, Tischendorf, F., Kirchheim, U., Reichardt, W. \& Bargholz, J. 2002. Effects of high fat rapeseed press cake on growth, carcass, meat quality and body fat composition of leaner and fatter pig crossbreeds. Animal Science 74: 285-297.

Smulikowska, S., Czerwiński, J. \& Mieczkowska, A. 2006. Nutritional value of rapeseed expeller cake for broilers: effect of dry extrusion. Journal of Animal and Feed Sciences 15: 445-453.

Suchy, P., Strakova, E., Vecerek, V. \& Slezackova, I. 2002. Replacement of animal origin feed by plant origin feed in the diet of broiler chicken. Czech Journal of Animal Science 47: 365-373.

Świątkiewicz, S. \& Koreleski, J. 2008. The use of distillers dried grains with solubles (DDGS) in poultry nutrition. World's Poultry Science Journal 64: 257-265

Titus, H.W., Mehring, A.L., Johnson, D., Nesbitt, L.L. \& Tomas, T. 1959. An evaluation of M.C.F. (Micro-Cel-Fat), a new type of fat product. Poultry Science, 38: 1114-1119.

Um, J.S. \& Paik, J.K. 1999. Effects of microbial phytase supplementation on egg production, eggshell quality, and mineral retention of laying hens fed different levels of phosphorus. Poultry Science 78: 75-79.

Żyła, K. \& Koreleski, J. 1993. In-vitro and in-vivo dephosphorylation of rapeseed meal by means of phytate degrading enzymes derived from Aspergillus niger. Journal of the Science of Food and Agriculture 61: 1-6.

Żyła K., Koreleski J., Świątkiewicz S., Ledoux D.R. \& Piironen J. 2001. Influence of supplemental enzymes on the performance and phosphorus excretion of broilers fed wheat-based diets to 6 weeks of age. Animal Feed Science and Technology 89: 113-118. 